\title{
Energetic costs of reproduction in female northern muriquis, Brachyteles hypoxanthus (Primates: Platyrrinhi: Atelidae)
}

\author{
Danusa Guedes ${ }^{1}$; Robert J. Young ${ }^{1} \&$ Karen B. Strier ${ }^{2}$ \\ ${ }^{1}$ Conservation, Ecology and Animal Behaviour Group, Mestrado em Zoologia de Vertebrados, Pontifícia Universidade \\ Católica de Minas Gerais. Avenida Dom José Gaspar 500, prédio 41, Coração Eucarístico, 30535-610 Belo Horizonte, \\ Minas Gerais, Brasil. \\ ${ }^{2}$ Department of Anthropology, University of Wisconsin-Madison, USA \\ ${ }^{3}$ Corresponding author. E-mail: robyoung@pucminas.br
}

\begin{abstract}
Infant care is known to impose high energetic costs on female primates because in addition to lactation, most primate mothers also provide transport for their offspring. Many studies have documented the high energetic costs of lactation, but less is known about energetic costs of infant carrying and their effects on the recovery of maternal physical condition. We compared the activities of female northern muriquis (Brachyteles hypoxanthus Kuhl, 1820) over a 12-month period at the RPPN Feliciano Miguel Abdala, Minas Gerais, Brazil to investigate whether mothers during their weaning year behaved differently than mothers in their post-weaning year, when they resumed reproductive cycling and copulating, and conceived again. We found no significant differences in the behavioral activity budgets of mothers in their weaning year $(n=4)$ versus post-weaning year $(n=5)$, despite the significantly higher proportion of time that mothers in their weaning year spent in close proximity with their infants and carrying their infants compared to mothers in their post-weaning year. We suggest that the energy budgets of weaning are similar to those of post-weaning in female northern muriquis. KEY WORDS. Activity; infant carrying; maternal energetics; reproduction weaning.
\end{abstract}

RESUMO. Os custos enérgeticos de reprodução em fêmeas de muirqui-do-norte (Primates: Platyrrinhi: Atelidae). $\mathrm{O}$ cuidado parental é conhecido por impor um elevado custo energético às fêmeas primatas, pois, além da lactação, muitas mães primatas também provêm transporte aos filhotes. Diversos estudos têm documentado o elevado custo energético da lactação, no entanto, pouco se sabe sobre o custo energético para o transporte do filhote e seus efeitos na recuperação da condição física das mães. Nós comparamos as atividades de fêmeas muriquis (Brachyteles hypoxanthus Kuhl, 1820), durante um período de 12 meses, na RPPN Feliciano Miguel Abdala, Minas Gerais Brasil, a fim de investigar se as mães durante o ano de desmame dos filhotes se comportavam diferentemente das mães no ano pós-desmame, quando elas recomeçaram o ciclo reprodutivo e de cópulas, e quando estavam concebendo novamente. Nós não encontramos nenhuma diferença significativa no orçamento das atividades comportamentais entre as mães no ano de desmame $(n=4)$ versus mães no ano pósdesmame $(\mathrm{n}=5)$, apesar das mães no ano de desmame terem gasto significativamente mais tempo em proximidade com seus infantes e carregado seus infantes do que as mães no ano pós-desmame. Nós sugerimos que, em fêmeas muriquis, o orçamento de energia do desmame é similar ao de pós-desmame.

PALAVRAS-CHAVE. Atividade; desmame; gastos energéticos maternais; reprodução; transporte de infantes.

Infant care is known to impose higher energetic costs on female mammals compared to other reproductive states, such as pregnancy, post-weaning recovery, and cycling and copulation, because of the costs of milk production during lactation (Altmann 1980, Dunbar et al. 2002, Lee 1996, Strier 1993). In many primates, infant care also involves other energetic costs associated with transporting infants and providing protection against predators or temperature. For example, carrying infants imposes high energetic costs on Callitrichidae primates (TARDIF
1997) and thermoregulation imposes high energetic costs on female Japanese macaques, Macaca fuscata Blyth, 1875 (Schino \& Troisi 1998). In chacma baboons, Papio ursinus Kerr, 1792, there is evidence that mothers have higher energetic costs in habitats with high predation risks (LyCETT et al. 1998).

Analysis of the behavior of female primates can provide insights into the different energetic costs associated with different reproductive states (Altmann 1980, Wrangham 1980, Barret et al. 1995, Lee 1996, Altmann \& Alberts 2005, Solanki et 
al. 2007). Several studies have reported that lactating females spend more time feeding than copulating or pregnant females: Papio cynocephalus Linnaeus, 1766, Altmann (1980), M. fuscata, TAKAHASHI (2002), Theropithecus gelada Rüppell, 1835, Dunbar et al. (2002), Cercopithecus aethipos Linnaeus, 1766, LeE \& HAUSER (1998). Lactating females have high energy requirements because of their need to transfer mass (energy) to their offspring (Lee 1996, Cameron 1998) and these requirements vary across species depending on infant mass and development from birth to weaning. The energetic costs of carrying infants can also vary across primate species, due to factors such as the distances that mothers must carry their offspring, the weight of the offspring, and access to allo-parental caretakers (TARDIF 1997, KRAMER 1998). For example, the heavy reliance on allo-parental care in carrying offspring in species of Callithrix Linnaeus, 1758 and Saguinus Linnaeus, 1758 compared to other smaller Neotropical primates may be related to the higher energetic costs associated with their more rapid rates of growth (TARDIF \& JACQUISH 1994). In addition, in Saguinus oedipus Linnaeus, 1758, individuals that carry infants have lower body weights than those that do not carry infants (SÁncheZ et al. 1999) and in common marmosets, Callithrix jacchus Linnaeus, 1758, TARDIF (1994) found a negative relationship between the weight of females and the number of ovulations. In baboons (LyCETT et al. 1998, Hill et al. 2000), low maternal weight can result in delays in the resumption of ovarian cycling.

Pregnancy generally imposes lower energy costs than lactation (Altmann 1980). However, females can modify their behavior to conserve and store energy, with impacts on offspring survival before and after birth (TARDIF et al. 2001).

The northern muriqui, Brachyteles hypoxanthus Kuhl, 1820 , is one of the largest Neotropical primates, and similar to species of two of the other genera in their family (Lagothrix and Ateles), their three years inter-birth intervals are relatively long compared to other monkeys of similar body weight (DI Fiore \& Campbell et al. 2007, Strier 1996, 1999b, 2003). Northern muriqui births are concentrated in the dry season and conceptions are concentrated in the rainy season, implying that the seasonal availability of food affects the timing of their reproduction (STRIER 1996, 2004).

We compared the behavior of northern muriqui females during their weaning year and during their post-weaning year, when they resumed copulating and reconceived. Weaning occurs during the second year of life, when milk is estimated to account for an average of $28.2 \%$ of infant diets. Unlike smaller Neotropical primates (TARdif 1997, SÁnchez et al. 1999, Digby et. al. 2007, STEVENSON \& RYLANDS 1998), northern muriquis females care alone for their offspring, and during the weaning year they still carry their offspring on long journeys. When the offspring is about 2.5 years old, mothers typically resume cycling and copulating, and if conception occurs, they give birth after a 7.2 month gestation (Strier \& Ziegler 1997). Consistent with studies on other species (eg. Altmann 1980, Dunbar et al. 2002), one comparison of northern muriqui females found that a female during her first year of lactation spent significantly more time feeding than a nonreproductive female, but there was no significant difference between her feeding time and that of a pregnant female (STRIER 1987). However, little is known about how the behavior or energetic costs of females in their weaning year compare to those of females in their post-weaning year.

Female northern muriquis usually experience a delay in the resumption of ovarian cycling and conception after weaning, which is thought to be related to the recovery of maternal physical condition in preparation for reproduction (STRIER et al. 2003). If the energetics associated with the resumption of cycling and pregnancy are similar to those associated with infant carrying during the weaning year, then the activity budgets $(\mathrm{eg}$. travel, feed and rest) of females in their weaning year should be similar to those of females during their post-weaning year.

Like chimpanzees and baboons, northern muriquis live in large mixed-sex groups, but unlike these primates, northern muriquis maintain an egalitarian society in which aggression is rare and there is no evidence of overt competition for food (Guimarães \& Strier 2001, Strier 1993, 1999a, Strier et al. 2002). Indeed, females avoid feeding competition by avoiding close proximity with other group members (STRIER 1990), and by fissioning into smaller feeding parties instead of increasing their day ranges (DiAs \& STRIER 2003). However, females with dependent offspring may associate with one another to give their infants opportunities to socialize (STRIER 1999a), which would lead to different social patterns between females in their weaning and post-weaning years. Specifically, we predicted that females in their weaning year would spend more time in association with other females with dependent offspring than females in their post-weaning year despite the predicted similarities in their activity budgets.

\section{MATERIAL AND METHODS}

This study was conducted from August 2004 to July 2005 at the RPPN Feliciano Miguel Abdala, in Minas Gerais, Brazil $\left(19^{\circ} 44^{\prime} \mathrm{S}, 41^{\circ} 49^{\prime} \mathrm{W}\right)$. This private reserve consists of 957 ha of semidecidual forest and is surrounded by pasture and plantations (Strier et al. 2006). Minimum and maximum temperatures during the study were 12 and $29^{\circ} \mathrm{C}$, respectively. The annual precipitation was $1,561 \mathrm{~mm}$, slightly above the average of 1,252 $\pm 426 \mathrm{~mm}$ (Strier et al. 2001).

The study subjects were nine adult females that had given birth in 2002 and 2003 in the Matão group, which had from 77 to 84 members this year. Mothers of offspring born in 2002 ( $\mathrm{n}=$ 5 ) were considered to be in their post-weaning; mothers of offspring born in $2003(n=4)$ were in their weaning year (Tab. I). All females in their post-weaning year copulated during the study and gave birth to new offspring in the later months of the study or in subsequent months. Although the majority of offspring were male, previous studies have shown that muriqui mothers do not invest differentially in sons and daughters (Tolentino et al. 2008). 
Table I. Focal subjects and their reproductive status.

\begin{tabular}{ccccc}
\hline Focal Females & Reproductive state & Offspring sex & Birth date of offspring & Offspring age in months during the study \\
\hline BA & Post-weaning & Male & August 2002 & $24-36$ \\
FE & Post-weaning & Male & October 2002 & $22-34$ \\
GA & Post-weaning & Male & August 2002 & $24-36$ \\
NY & Post-weaning & Female & November 2002 & $21-33$ \\
PL & Post-weaning & Male & September 2002 & $23-35$ \\
YA & Weaning & Male & August 2003 & $12-24$ \\
JU & Weaning & Female & March 2003 & $17-29$ \\
VD & Weaning & Male & May 2003 & $15-27$ \\
IZ & Weaning & Male & June 2003 & $14-26$ \\
\hline
\end{tabular}

We recorded the activities of mothers and mother-offspring distances during on-the-minute observations of focal females (MARTIN \& BATESON 1993). Focal samples were $10 \mathrm{minu}$ tes in duration, and the samples were discarded if an individual was lost to view for more than two minutes during a sampling period. The activities recorded were adapted from previous studies on this group (Strier 1987, Printes \& STrier 1999): resting, traveling, feeding (ingesting food), socializing (eg. embraces, play, and agonistic interactions), mother-offspring interactions (socializing between the mother and her offspring), and drinking water. When the focal subject was feeding, we also recorded the item ingested (fruit, young leaf, mature leaf, flower, other item) and when she was traveling we recorded whether she was carrying her offspring. The mother-offspring distances were distinguished as: In contact, within a $1 \mathrm{~m}$ radius, within a $5 \mathrm{~m}$ radius, and outside of a $5 \mathrm{~m}$ radius.

During the focal observation periods, we also recorded any neighbor within a $5 \mathrm{~m}$ radius of the focal female. The 76 individuals in the study group (excluding the focal females and their infants, and individuals that died or emigrated during the first two months of the study, or were born or immigrated during the last two months) were classified into six neighbor categories, in accordance with STRIER (1993): Adult males ( $\mathrm{n}=$ $20)$, young males $(n=9)$, adult females without dependent offspring $(n=8)$, young females $(n=13)$, females with dependent offspring $(n=13)$ and dependent offspring $(n=13)$.

We used a similar protocol employed in previous muriqui studies to reduce bias and maintain the independence of the focal samples (Printes \& STrier 1999). We used Mann-Whitney $\mathrm{U}$ tests to compare the mean monthly proportion of time mothers devoted to different activities and spent in proximity to their infants in their weaning versus post-weaning years. We divided the year into rainy and dry periods based on months with $\geqslant 100$ and $<100 \mathrm{~mm}$ of rainfall, respectively. This resulted in three periods: Dry season 1 (August to October 2004), Rainy season (November 2004 to March 2005) and Dry season 2 (April to July 2005). We used Friedman tests (Siegel 1975) to compare the mean monthly proportion of time of weaning versus postweaning mothers in different activities across all periods.
We used the chi-square test to analyze the female neighbor relationships. The expected frequencies for each category of neighbor with the two types of focal females were calculated from the total number of records of neighbors (the number of individuals in each category the 76 individuals in the group, excluding the focal female and her infant). If the results of the chi-square test were significant $(p<0.05)$, we submitted the results to standardized residual analysis (SIEGEL 1975).

\section{RESULTS}

In total, we recorded 5,205 minutes of activities during 530 samples of focal females in their post-weaning year, and 3,034 minutes during 306 samples of focal females in their weaning year. We found no significant differences in the average proportion of time that females in their weaning and nonweaning years devoted to different activities (Tab. II). Females in their weaning year appeared to devote significantly more of their time to feeding on flowers than females in their postweaning year during Dry season 2, but this effect was due to the exceptionally high proportion of feeding on flowers by only one of the four weaning-year females (Tab. III).

Females in their weaning year spent an average of $56.80 \pm 26.72 \%(n=4)$ of their travel time carrying offspring. The three of the five post-weaning females that carried their offspring did so for an average of $25.18 \pm 21.80 \%(n=3)$. The average proportion of travel time that females carried offspring was negatively correlated with the age of the offspring (Spearman Rank correlation: $r_{s}=-0.75, n=24, p<0.001$ ), and none of the offspring were carried when their mothers were traveling after they had reached 26 months of age.

Females in their weaning year spent significantly more time in contact with their offspring (Mann-Whitney: $\mathrm{W}=16.0$, $\mathrm{N}_{1}=4, \mathrm{~N}_{2}=5$, Mean $\pm \mathrm{SE}_{1}=16.86 \pm 1.67 \%$, Mean $\pm \mathrm{SE}_{2}=10.37$ $\pm 1.38 \%, \mathrm{p}<0.05$ ) and within a $1 \mathrm{~m}$ radius of their offspring (Mann-Whitney: $\mathrm{W}=15.0, \mathrm{~N}_{1}=4 \mathrm{~N}_{2}=5$, Mean $\pm \mathrm{SE}_{1}=20.32 \pm$ $1.53 \%$, Mean $\left.\pm \mathrm{SE}_{2}=13.15 \pm 1.12 \%, \mathrm{p}<0.05\right)$ than females in their post-weaning year. There were no differences in the percentage of time that females in their weaning and post-wean years spent within a $5 \mathrm{~m}$ radius $\left(\mathrm{W}=23.0, \mathrm{~N}_{1}=4, \mathrm{~N}_{2}=5\right.$, Mean \pm 
Table II. Mean \pm SE \% of mean time devoted to different activities.

\begin{tabular}{lccc}
\hline \multirow{2}{*}{$\begin{array}{c}\text { Behavior and food item } \\
\text { consumed }\end{array}$} & \multicolumn{2}{c}{ Mean \pm standard error of percentage of time } \\
\cline { 2 - 4 } & Females in weaning year & Females in post-weaning year & Mann Whitney U test $(W)$ results and their "p" values \\
\hline Feeding & $39.76 \pm 1.57$ & $39.86 \pm 2.16$ & $W=27, p=0.713, N_{1}=4, N_{2}=5$ \\
Fruit & $17.56 \pm 2.38$ & $16.81 \pm 2.01$ & $W=24, p=0.902, N_{1}=4, N_{2}=5$ \\
Young leaf & $2.59 \pm 0.55$ & $4.08 \pm 1.02$ & $W=29, p=0.391, N_{1}=4, N_{2}=5$ \\
Mature leaf & $13.62 \pm 0.84$ & $14.60 \pm 1.47$ & $W=29, p=0.3913, N_{1}=4, N_{2}=5$ \\
Flower & $5.27 \pm 1.38$ & $3.55 \pm 1.02$ & $W=20, p=0.270, N_{1}=4, N_{2}=5$ \\
Resting & $39.80 \pm 2.60$ & $43.56 \pm 4.00$ & $W=27, p=0.713, N_{1}=4, N_{2}=5$ \\
Traveling & $17.64 \pm 1.08$ & $14.69 \pm 2.10$ & $W=21, p=0.391, N_{1}=4, N_{2}=5$ \\
Socializing & $1.41 \pm 0.57$ & $1.42 \pm 0.39$ & $W=25, p=1.000, N_{1}=4, N_{2}=5$ \\
Interaction with & $0.65 \pm 0.41$ & $0.20 \pm 0.15$ & $W=23, p=0.713, N_{1}=4, N_{2}=5$ \\
offspring & $0.74 \pm 0.47$ & $0.27 \pm 0.15$ & $W=22.5, p=0.624, N_{1}=4, N_{2}=5$ \\
Drinking water & & &
\end{tabular}

Table III. Mean \pm SE \% of mean time devoted to different activities across seasons.

\begin{tabular}{|c|c|c|c|c|c|c|}
\hline \multirow{2}{*}{ Behavior and food items } & \multirow{2}{*}{$\frac{\text { Females in weaning year }}{\text { Dry season } 1}$} & \multicolumn{5}{|c|}{ Females in post-weaning year } \\
\hline & & Rainy season & Dry season 2 & Dry season 1 & Rainy season & Dry season 2 \\
\hline Feeding & $30.46 \pm 5.67$ & $44.24 \pm 5.55$ & $48.05 \pm 2.68$ & $28.42 \pm 3.90$ & $45.94 \pm 2.36$ & $40.67 \pm 2.29$ \\
\hline Fruit & $12.06 \pm 5.08$ & $30.93 \pm 6.48$ & $14.42 \pm 2.45$ & $6.07 \pm 1.06 \mathrm{~F}$ & $25.53 \pm 4.96 \mathrm{~F}$ & $13.39 \pm 2.56$ \\
\hline Young leaf & $3.19 \pm 1.23$ & $5.02 \pm 3.61$ & 0.00 & $1.12 \pm 0.67$ & $7.54 \pm 2.10$ & $1.93 \pm 0.92$ \\
\hline Mature leaf & $9.93 \pm 1.30$ & $7.39 \pm 2.86$ & $22.91 \pm 0.85$ & $18.22 \pm 3.33$ & $9.13 \pm 3.13$ & $19.16 \pm 1.65$ \\
\hline Flower & $4.79 \pm 2.52$ & $0.19 \pm 0.19$ & $9.70 \pm 1.23 \mathrm{~W}$ & $2.38 \pm 0.91$ & $2.99 \pm 2.05$ & $5.17 \pm 0.89 \mathrm{~W}$ \\
\hline Resting & $48.22 \pm 4.78$ & $27.88 \pm 2.16$ & $38.20 \pm 1.08$ & $52.12 \pm 6.09$ & $37.49 \pm 4.65$ & $45.00 \pm 3.07$ \\
\hline Traveling & $18.90 \pm 2.31$ & $24.58 \pm 2.16$ & $10.85 \pm 2.71$ & $16.46 \pm 2.99$ & $15.26 \pm 2.93$ & $12.57 \pm 1.27$ \\
\hline Socializing & $0.56 \pm 0.20$ & $1.38 \pm 1.04$ & $2.50 \pm 0.79$ & $2.71 \pm 10.59$ & $0.87 \pm 0.56$ & $1.16 \pm 0.59$ \\
\hline Drinking water & $0.30 \pm 0.30$ & $1.93 \pm 1.93$ & $0.40 \pm 0.15$ & $0.07 \pm 0.07$ & $0.14 \pm 0.06$ & $0.59 \pm 0.43$ \\
\hline Interaction with offspring & $1.56 \pm 1.00$ & 0.00 & 0.00 & $0.22 \pm 0.08$ & $0.31 \pm 0.31$ & 0.00 \\
\hline
\end{tabular}

(W) See text for details on this difference; $(F)$ Fruit consumption by females in their post-weaning year differed significantly across seasons. Post-hoc Tukey: $\mathrm{Fr}=7.00, \mathrm{df}=2, \mathrm{p}<0.05$.

$\mathrm{SE}_{1}=40.88 \pm 2.10 \%$, Mean $\left.\pm \mathrm{SE}_{2}=40.89 \pm 3.38 \%, \mathrm{p}=0.713\right)$ or outside $5 \mathrm{~m}$ of their offspring $\left(\mathrm{W}=33.0, \mathrm{~N}_{1}=4, \mathrm{~N}_{2}=5\right.$, Mean \pm $\mathrm{SE}_{1}=21.93 \pm 1.34$, Mean $\pm \mathrm{SE}_{2}=35.58 \pm 4.23, \mathrm{p}=0.066$ ) (Fig. 1).

All members of the group were recorded as neighbors of all focal females on at least one occasion. The frequencies of neighbor categories differed significantly from expectations based on their representation in the group for females in their weaning year $\left(\mathrm{x}^{2}=65.33\right.$, df $\left.=5, \mathrm{p}<0.05\right)$ and post-weaning year $\left(\mathrm{x}^{2}=55.29\right.$, $\left.\mathrm{df}=5, \mathrm{p}<0.05\right)$. The standardized residuals revealed that females in their weaning year were observed significantly more often than expected in proximity with other females with dependent offspring, and significantly less often in proximity with young and old males. By contrast, females in their post-weaning year were observed significantly more often than expected in proximity with adult females with or without dependent offspring, and significantly less often in proximity with both young males and young females (Fig. 2).

\section{DISCUSSION}

Consistent with our predictions, there were no differences in the activity budgets between females in their weaning versus non-weaning years, and females in their weaning year spent more time in proximity with their offspring and more time carrying their offspring than females in their post-weaning year. The similarity we found in the females' activity budgets differs from results of a previous study, when females in their weaning year devoted more time to feeding than pregnant females. Although the average proportion of time that females in their weaning year devoted to feeding was similar in the two studies, sample did not include females during the post-weaning to conception period, which might have affected his results. In addition, different ecological and demographic 

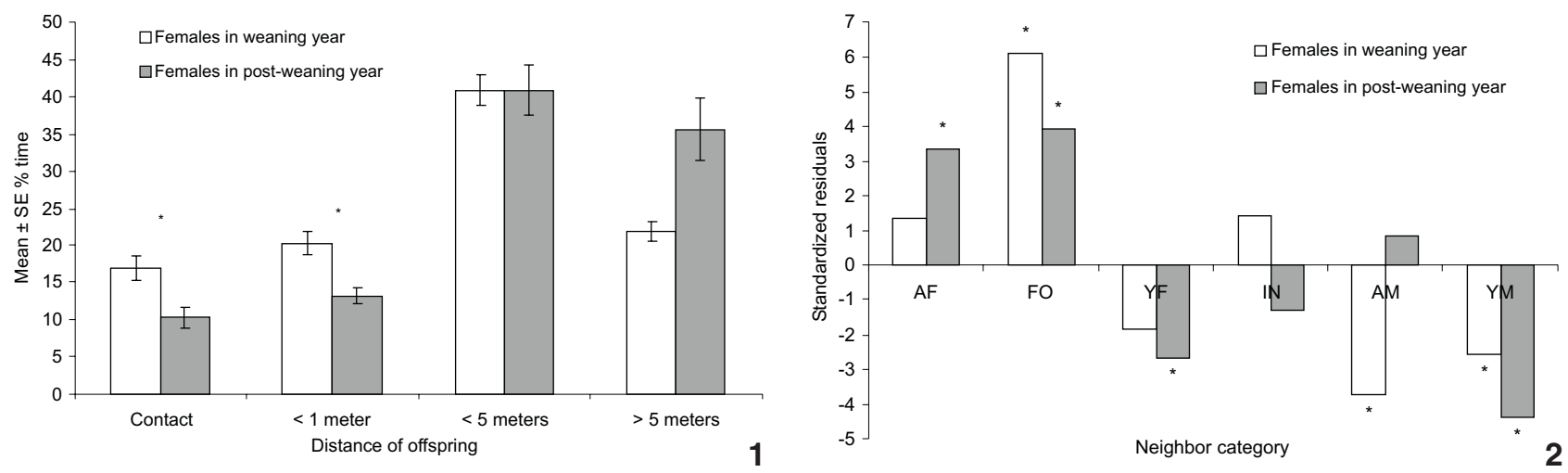

Figures 1-2. (1) Mean \pm SE\% of mean time mother-offspring distances. ( $\left.{ }^{*}\right)$ Significant differences between females in their weaning and post-weaning years. (2) 2. Standardized residuals of Chi-square test for neighbor categories. (AF) = Adult females, (FO) $=$ females with dependent offspring, (YF) = young females, $(I N)=$ infants, $(A M)=$ adult males, $(Y M)=$ young males. $\left(^{*}\right)$ Statistical significance was considered when the residuals were greater than +2 or -2 .

conditions could have affected the females' behavior during each of the study periods.

In accord with our prediction, females in their weaning year were observed in proximity with other females with dependent offspring more often than expected. This may reflect similar activity patterns among females with dependent infants, and is consistent with the idea that proximity provides opportunities for young offspring to socialize (STRIER 1999a). We found differences in the proximity of females in their weaning and post-weaning years with adult males, which may be related to differences in the females' sexual activity. All of the females in their post-weaning year resumed copulating, which may have made them more attractive to males than sexually inactive females in their weaning year (Strier \& Ziegler 1994, 1997). Due to their philopatric social structure the risk of infanticide by male muriquis is considered minimal and this is supported by a study of adult male-infant interactions, which showed their interactions to be non-aggressive and very rare (GUIMARÃES \& Strier 2001). Possamai et al. (2007) found a positive relationship between the proportion of time that some females spent in proximity with males and their copulation frequencies, suggesting that at least some male-female spatial relationships may be associated with sexual interactions.

Our results suggest that although the energetic costs of reproduction in female northern muriquis may differ over their 3-year birth interval (STRIER 1999b, 2003), their energy budgets may be similar for different reasons (Fig. 3). During the first year post-partum, female energetic requirements are primarily associated with cost of lactation, but during the weaning year, they are primarily associated with infant carrying, which becomes more costly as the body mass of the offspring increases (Altmann 1980). Females may need to draw on their energy reserves during both their lactation and weaning years, resulting in weight loss, as has been observed in lactating baboons

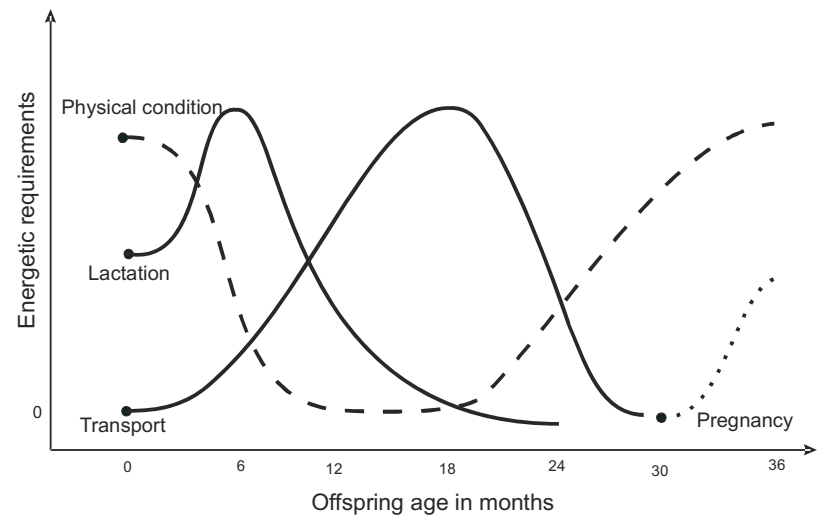

Figure 3. Graphical model representing changes in female energetic requirements across reproductive phases.

(BERCOVITCH 1987) and poor physical condition, as has been observed in female marmosets that were carrying infants (SÁnCHEZ et al. 1999), respectively. Female muriquis may reduce their investment in lactation after the first six months in order to sustain the rising energetic costs of carrying growing offspring. We consider that carrying offspring is energetically costly for female muriquis because in addition to traveling more than one kilometer, on average, per day (Dias \& STRIER 2003), their suspensory locomotion is more energetically expensive than the quadruped locomotion employed by most other primate species (Leonard \& Robertson 1997, Steudel-Numbers 2003).

In the post-weaning year, when females have ceased to carry their offspring, they may switch to recovering their energetic reserves for subsequent reproductive cycling and pregnancy. STRIER et al. (2003) showed that female muriquis have significantly higher levels of cortisol during the post-weaning/anovulatory and cycling/copulation phases than males, which can be 
attributed to the energetics required for cycling and pregnancy. The recovery of female physical condition prior to the resumption of cycling and conception is also known to be important in other primates (Baboons: Bercovitch 1987, AtLmann 1980, LyCETT et al. 1998, spider monkeys: Fedigan \& Rose 1995).

Although infant carrying in muriquis ceases when their infants are 26 months of age, mothers may continue to help their offspring to traverse wide gaps in the canopy by using their bodies as a "bridge" between the branches. However, there is no evidence of consistent, preferential associations or interactions between mothers and their older offspring that could be interpreted as energetically expensive investment (TolENTINO et al. 2008).

The energetic requirements of pregnant females may be focused on conserving energy in preparation for dry season births, when energy rich foods are scarce (STRIER 1991, 2004, STRIER et al. 2001). Female Leontopithecus rosalia Linnaeus, 1766, are also thought to store energy for copulation, pregnancy and the early months after birth (Miller et al. 2006).

Our interpretation of the similar energetic requirements of muriqui females in their weaning and post-weaning years emphasizes the non-lactational costs of reproduction (Fig. 3). Future research focused on behavior and physiology, including female weights, during the weaning and post-weaning years is needed to evaluate the generality of our findings to other primates with different reproductive and infant caretaking patterns.

\section{ACKNOWLEDGMENTS}

We thank CNPq for permission to conducted this research, the Abdala family for permission to work in the reserve, and to CI-Brasil, University of Wisconsin-Madison and Sergio Mendes for logistical support. We also thank the National Geographic Society, Margot Marsh Biodiversity Foundation, Liz Clairborne and Art Ortenberg Foundation for grants to KBS in support of the field component of this research, and CNPq for a post-graduate research scholarship to DG during the analyses component.

\section{LITERATURE CITED}

Altmann, J. 1980. Baboon Mothers and Infants. Cambridge, Harvard University Press, 242p.

Altmann, J. \& S.C. AlberTs. 2005. Growth rates in a wild primate population: ecological influences and maternal effects. Behaviour Ecology Sociobiology 57 (5): 490-501.

Barret, L.; R.I.M. Dunbar \& P. Dunbar. 1995. Mother-infant contact as contingent behaviour in gelada baboons. Animal Behaviour 49 (3): 850-810.

Bercovitch, F.B. 1987. Female weight and reproductive condition in a population of olive baboons (Papio anubius). American Journal of Primatology 12 (2): 189-195.

CAMERon, E.Z. 1998. Is suckling behaviour a useful predictor of milk intake? Animal Behaviour 56 (3): 521-532.
Dias, L.G. \& K.B. Strier. 2003. Effects of groups size on ranging patterns in Brachyteles arachnoides hypoxanthus. International Journal of Primatology 24 (2): 209-221.

Di Fiore, A. \& C.J. Campbell. 2007. The atelines variation in ecology, behaviour and social organization, p. 155-185. In: C.J. Campbell; A. Fuentes; K.C. MacKinnon; M. Panger \& S.K. Bearder (Eds). Primates in perspective. Oxford, Oxford University Press, 736p.

Digby, L.J.; S.F. Ferrari \& W. Satzman. 2007. Callithrichines, p. 85105. In: C.J. Campbell; A. Fuentes; K.C. MacKinnon; M. PAnger \& S.K. BEARDER (Eds). Primates in perspective. Oxford, Oxford University Press, 736p.

Dunbar, R.I.M.; L. Hannah-Steward \& P. Dunbar. 2002. Forage quality and cost of lactation for female gelada baboons. Animal Behaviour 64 (5): 801-805.

Fedigan, L.M. \& L.M. Rose. 1995. Interbirth interval in three sympatric species of neotropical primates. American Journal of Primatology 37 (1): 9-24.

GuimarÃEs, V.O. \& K.B. StRIER. 2001. Adult male-infant interactions in wild muriquis (Brachyteles arachnoides hypoxanthus). Primates 42 (4): 395-399.

Hill, R.A.; J.E. Lycett \& R.I.M. Dunbar. 2000. Ecological and social determinants of birth intervals in baboons. Behavioral Ecology 11 (5): 550-554.

KRAMER, P.N. 1998. The cost of human locomotion: maternal investment in child transport. American Journal of Physical Anthropology 107 (1): 71-85.

LEE, P.C. 1996. The meaning of weaning: growth, lactation, and life history. Evolutionary Anthropology 5 (3): 87-96.

Lee, P.C. \& M.D. Hauser. 1998. Long-term consequences of changes in territory quality on feeding and reproductive strategies of vervet monkeys. Journal of Animal Ecology 67 (3): 347-358.

Leonard, W.R. \& M.L. Robertson. 1997. Comparative primate energetic and hominid evolution. American Journal of Physical Anthropology 102 (2): 265-281.

Lycett, J.E.; P. Henzi \& L. Barret. 1998. Maternal investment in mountain baboons and the hypothesis of reduced care. Behaviour Ecology and Sociobiology 42 (1): 49-56.

Martin, P. \& P. BAteson. 1993. Measuring Behaviour: an introductory guide. New York, Cambridge University Press, $2^{\text {nd }}$ ed., 222p.

Miller, K.E.; K.L. Bales; J.H. Ramos \& J.M. Dietz. 2006. Energy intake, energy expenditure, and reproductive cost of female wild golden lion tamarins (Leontopithecus rosalia). American Journal of Primatology 68 (11): 1037-1053.

Possamai, C.B.; R.J. Young; S.L. Mendes \& K.B. Strier. 2007. Sociosexual behaviour of females northern muriquis (Brachyteles hypoxanthus). American Journal of Primatology 69 (7): 766776.

PRINTES, R.C. \& K.B. STRIER. 1999. Behavioral correlates of dispersal in females muriquis (Brachyteles arachnoides). International Journal of Primatology 20 (6): 941-960. 
Sánchez S.; F. Peláez; C. Gil-Bürmann \& W.Kaumanns. 1999. Cost of infant-carring in cotton-top tamanrin (Saguinus oedipus). American Journal of Primatology 48 (2): 99-111.

Schino, G. \& A. Troisi. 1998. Mother-infant conflict over behaviour thermoregulation in Japanese macaques. Behaviour Ecology and Sociobiology 43 (2): 81-86.

SIEGEL, S. 1975. Estatística não paramétrica: para as ciências do comportamento. São Paulo, Ed. McGraw-Hill, 350p.

SOLANKI, G.S.; A. Kumar \& B.K. Sharma. 2007. Reproductive strategies of Trachypithecus pileatus in Arunachal Pradesh, India. International Journal of Primatology 28 (5): 1075-1083.

Steudel-Numbers, K.L. 2003. The energetic cost of locomotion: humans and primates compared to generalized endotherms. Journal of Human Evolution 44 (2): 255-262.

Stevenson, M.F. \& A.B. Rylands. 1988. The marmosets, genus Callithrix, p. 131-222. In: R.A. Miettermeier; A.B. Rylands; A.F. Coimbra-Filho \& G.A.B. Fonseca (Ed.). Ecology and Behaviour of Neotropical Primates. Washington, World Wildlife Fund, vol. 2, 610p.

StRIER, K.B. 1987. Activity budgets of woolly spider monkeys, or muriquis (Brachyteles arachnoides). American Journal of Primatology 13 (4): 385-395.

STRIER, K.B. 1990. New World primates, new frontiers: Insights from the woolly spider monkey, or muriqui (Brachyteles arachnoids). International Journal of Primatology 11 (1): 7-19.

StRier, K.B. 1991. Diet in one group of woolly spider monkeys, or muriquis (Brachyteles arachnoides). American Journal of Primatology 23 (2): 113-126.

StrIER, K.B. 1993. Growing up in a patrifocal society: sex differences in the special relation of immature muriquis, p. 138147. In: M.E. Pereira \& L.A. FAIRBANKS (Eds). Juveniles primates: life history, development and behaviour. New York, Oxford University Press, 461p.

Strier, K.B. 1996. Reproductive ecology of female muriquis, p. 11-532. In: M.A. Norconk; A.L. Rosenberger \& P.A. Garber (Eds). Adaptative radiations of Neotropical primates. New York, Plenus Press, 555p.

Strier, K.B. 1999a. Faces in the forest. Cambridge, Harvard University Press, 138p.

Strier, K.B. 1999b. The atelines, p. 109-114. In: P. Dolhinon \& A. Fuontes (Ed). The nonhuman primates. Mountain View, Mayfield Publishers, 340p.

Strier, K.B. 2003. Primatology comes of age: 2002 AAPA luncheon address. Yearbook of Physical Anthropology 46 (37): 2-13.

STRIER, K.B. 2004. Reproductive strategies of new world primates: interbirth intervals and reproductive rates. A Primatologia no Brasil 8: 53-63.

Strier, K.B. \& T.E. Ziegler. 1994. Insights into ovarian function in wild muriqui monkeys (Brachyteles arachnoides). American Journal of Primatology 32 (1): 31-40.

Strier, K.B. \& T.E. Ziegler. 1997. Behaviour and endocrine characteristics of the reproductive cycles in wild muriqui monkeys, Brachyteles arachnoides. American Journal of Primatology 42 (4): 299-310.STRIER, K.B.; S.L Mendes \& R.R. SANTOS. 2001. Timing of births in sympatric brown howler monkeys (Alouatta fusca clamitans) and northern muriquis (Brachyteles arachnoides hypoxanthus). American Journal of Primatology 55 (2): 87-100.

Strier, K.B; L.T. Dib \& J.E.C. Figueira. 2002. Social dynamics of male muriquis (Brachyteles arachnoides hypoxanthus). Behaviour 139 (2): 315-342.

Strier, K.B.; J.W. Lynch \& T.E. Ziegler. 2003. Hormonal changes during the mating and conception season of wild northern muriquis (Brachyteles arachnoides hypoxanthus). American Journal of Primatology 61 (6): 85-99.

Strier, K.B.; J.R. Boubli; C.B. Possamai \& S.L. Mendes. 2006. Population demography of northern muriquis (Brachyteles hypoxanthus) at Estação Biologica de Caratinga Reserve Particular do Patrimônio Natural-Feliciano Miguel Abdala, Minas Gerais, Brazil. American Journal of Physical Anthropology 130 (2): 180-237.

TAKAHASHI, H. 2002. Female reproductive parameters and fruit availability: factors determining onset of estrus in Japanese macaques. American Journal of Primatology 51 (3): 141-153.

TARDIF, S.D. 1997. The bioenergetics of parental behaviour and evolution of alloparental care in marmosets and tamarins, p. 11-33. In: N.G., Solomon, J.A. French (Eds). Cooperative breeding in mammals. Cambridge, Cambridge University Press, 402p.

TARDIF, S.D. 1994. Relative energetic cost of infant care in smallbodied neotropical primates and its relation to infant-care patterns. American Journal of Primatology 34 (2): 133143.

TARDIF, S.D. \& C.E. JAQUish. 1994. The common marmoset as a model for nutritional impacts upon reproduction. Annuals of the New York Academy of Science 709 (1): 214-215.

Tardif, S.D.; M., Power; O.T., Oftedal; R.A., Power \& D.G., Layane. 2001. Lactation, maternal behaviour and infant growth in common marmoset monkeys (Callithrix jacchus): effects of maternal size and litter size. Behaviour Ecology and Sociobiology 51 (1): 17-25.

Tolentino K.; J.J. Roper; F.C. Passos \& K.B. Strier. 2008. Motheroffspring associations in northern muriquis, Brachyteles hypoxanthus. American Journal of Primatology, 70 (3): 301305.

Wrangham, R.W. 1980. An ecological model of female-bonded primate groups. Behaviour 75 (3-4): 262-299.

Received: 11.VI.2008; Accepted: 03.XII.2008.

Editorial responsibility: Kleber del Claro 